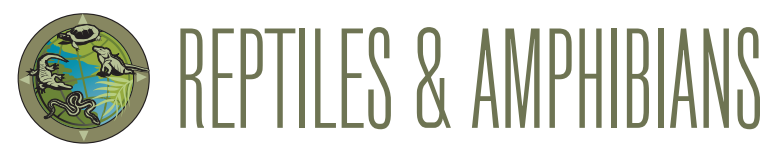

\title{
A Beauty Snake, Elaphe taeniura (Cope 1861) (Squamata: Serpentes: Colubridae), from the Itanagar Wildlife Sanctuary, Arunachal Pradesh, India
}

\author{
Kirty Prosad Nath ${ }^{1}$ and Bikramjit Sinha ${ }^{2}$
}

${ }^{1}$ Arunachal Pradesh Regional Centre, Zoological Survey of India, Senki Valley, Itanagar 791113, Arunachal Pradesh, India ${ }^{2}$ North Eastern Regional Centre, Zoological Survey of India, Risa Colony, Shillong 793003, Meghalaya, India (bj.sinha@gov.in)

$\mathrm{O}$ f 16 currently recognized species in the genus Elaphe, three (E. cantoris, E. hodgsoni, E. taeniura) are known to occur in India (Sharma 2002; Uetz et al. 2021), where they are distributed mainly in the western and eastern Himalayan regions. Two of those species (E. cantoris, E. taeniura) have been recorded in the eastern Himalayan state of Arunachal Pradesh (Sharma 2003; Borang et al. 2005; Uetz et al. 2021), where the Beauty Snake (E. taeniura) occurs mainly in the foothills. This species has been reported from Namdapha National Park in Changlang District (Bhatt 2004; Sanyal and Gayen 2006), Dihang-Dibang Biosphere Reserve in Upper Dibang Valley District (Borang 2003), Lohit District (Choudhury 1978), Upper Siang District (Sanyal and Gayen 2006), and both Lower and Upper Subansiri Districts (Bhatt 2004). Herein,

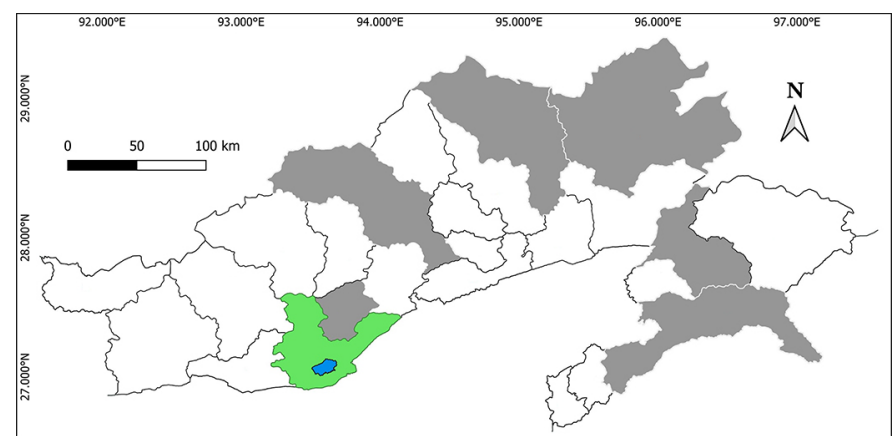

Fig. 1. Map of Arunachal Pradesh, India, showing districts in which the Beauty Snake (Elaphe taeniura) has been recorded previously marked in gray. Papumpare District, site of the new record, is indicated in green and the Itanagar Wildlife Sanctuary in blue.
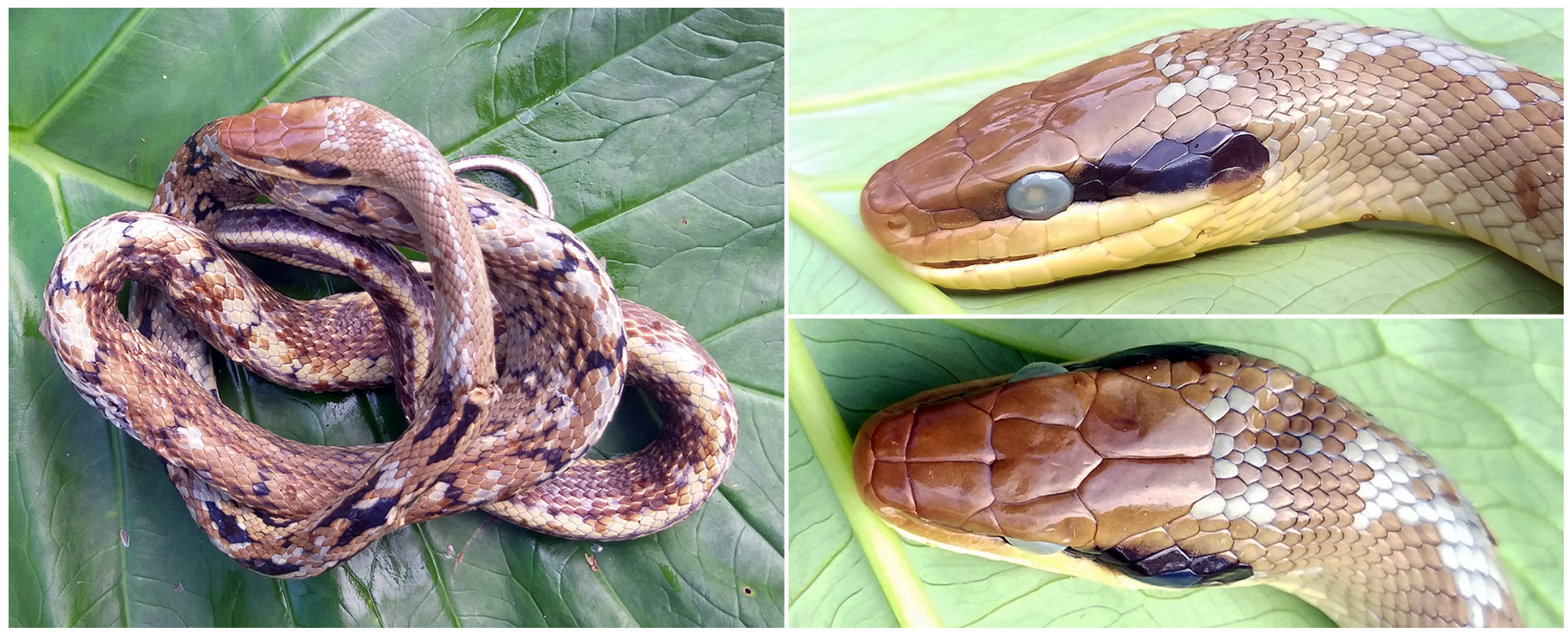

Fig. 2. Road-killed Beauty Snake (Elaphe taeniura) from the Itanagar Wildlife Sanctuary, Papumpare District, Arunachal Pradesh, India. Photographs by Kirty Prosad Nath. 
we report the first record of E. taeniura from Itanagar Wildlife Sanctuary in Papumpare District (Fig. 1).

Local residents found a road-killed male Beauty Snake (SVL 1,056 mm, TL $268 \mathrm{~mm}$ ) (Fig. 2) on the PWD Road, Senki Valley, Itanagar Wildlife Sanctuary, Papumpare District, Arunachal Pradesh $\left(27.077^{\circ} \mathrm{N}, 93.597^{\circ} \mathrm{E}\right.$; elev. $\left.232 \mathrm{~m}\right)$, and donated it to the Zoological Survey of India (ZSI), Arunachal Pradesh Regional Centre (APRC), Itanagar (APRC/R-168). The specimen was identified as Elaphe taeniura based on the morphological features listed in Sharma $(2003,2007)$ and Sanyal and Gayen (2006). The identity of the species was confirmed by Dr. B.B. Bhatt. This report documents the occurrence of the species in the seventh district and third protected area in Arunachal Pradesh, and represents the southern- and westernmost record of the species in the state.

\section{Acknowledgements}

We thank the Director, Zoological Survey of India, and the Officer-in-Charge, Arunachal Pradesh Regional
Centre and North Eastern Regional Centre of ZSI, for their support.

\section{Literature Cited}

Bhatt, B.B. 2004. Present Status of Ophidian Fauna with Habitat Ecology of Certain Opecies of Ophidians in Arunachal Pradesh. Unpublished Ph.D. Thesis, Gauhati University, Guwhati, Assam, India.

Borang, A. 2003. Checklist of reptilian fauna of Dihang Dibang Biosphere Reserve in Northeast India. Himalayan Biosphere Reserve 5: 61-68.

Borang, A., B.B. Bhatt, S.B. Chaudhury, A. Borkotoki, and P.T. Bhutia. 2005. Checklist of the snakes of Arunachal Pradesh, Northeast India. Journal of the Bombay Natural History Society 102: 19-26

Choudhury, S.D. 1978. Arunachal Pradesh District Gazetteer. Lohit District. Government of Arunachal Pradesh, Shillong, India.

Sanyal, D.P. and N.C. Gayen. 2006. Reptilia, pp. 247-284. In: J.R.B. Alfred (ed.), Fauna of Arunachal Pradesh (Part-1). State Fauna Series 13, Zoological Survey of India, Kolkata, India.

Sharma, R.C. 2002. Fauna of India and the Adjacent Countries. Reptilia. Volume-III (Serpentes). Zoological Survey of India, Kolkata, India.

Sharma, R.C. 2003. Handbook. Indian Snakes. Zoological Survey of India, Kolkata, India.

Uetz, P., P. Freed, R. Aguilar, and J. Hošek (eds.). 2021. The Reptile Database. $<$ http://www.reptile-database.org $>$. 